\title{
Seasonal abundance and molecular identification of West Nile virus vectors, Culex pipens and Culex quinquefasciatus (diptera: culicidae) in Abeokuta, South-West, Nigeria.
}

\author{
Babatunde Olanrewaju Motayo ${ }^{1}$, Bernard Aneibe Onoja ${ }^{2}$, Adedayo Omotayo Faneye ${ }^{2}$, Johnson Adekunle Adeniji ${ }^{2}$
}

1. Federal Medical Centre, Microbiology Unit, Pathology Department.

2. University of Ibadan, Virology.

\begin{abstract}
:
Background: West Nile virus (WNV) infection, is an arbovirus infection with high morbidity and mortality, the vector responsible for both human and animal transmission is Culex pipens complex.

Objective: To determine the species distribution and seasonal abundance of Culex pipens and Culex quinquefasciatus mosquitoes in Abeokuta, Nigeria.

Methods: Mosquitoes belonging to the Culexpipens complex were captured in three different locations located within Abeokuta Metropolis between March 2012 and January 2013. Individual species were identified using morphometric methods. Amplification of the Ace2 gene by PCR confirmed morphormetric identification of the mosquitoes.

Results: A total of 751 mosquitoes were captured. Culex quinquefaciatus recorded the highest distribution of vectors with $56.6 \%$ and Culexpipens 43.4\% (P > 0.05). Idi aba community recorded the highest distribution of mosquito vectors with $42.9 \%(\mathrm{n}=322)$ and Culex quinqueaciatus was more abundantly distributed with 183 mosquitoes. Aro community recorded 32\% (n=240) of captured mosquitoes with Culex quinquefaciatus having a higher level of abundance and lastly Kemta with a distribution of $25.1 \%$ $(\mathrm{n}=189)$.

Conclusion: Results from this study show that potential vectors of WNV abound within Abeokuta, putting residents at high risk of West Nile infection. We advocate for introduction of routine testing of WNV in Abeokuta and Nigeria.

Keywords: West Nile Virus, Culex pipens complex, PCR, Abeokuta.

DOI: http://dx.doi.org/10.4314/ahs.v16i1.18

Cite as: Motayo BO, Onoja BA, Faneye AO, Adeniji JA. Seasonal abundance and molecular identification of West Nile virus vectors, Culex pipens and Culex quinquefasciatus (diptera: culicidae) in Abeokuta, South-West, Nigeria. Afri Health Sci. 2016;16(1): 135-140. bttp:/ / dx.doi. org/10.4314/ahs.v16i1.18
\end{abstract}

\section{Introduction}

Mosquitoes (Diptrea) are principal vehicles in the transmission of various diseases, mainly viral and parasitic. Major diseases transmitted are known as Arboviral diseases because these viral infections are transmitted by arthropod vectors ${ }^{1}$. Human and animal pathogenic arboviruses include, WestNile virus, (WNV), Yellow fever virus (YFV), Dengue virus (DNV) and Rift valley fever virus (RVFV) ${ }^{1}$. In Africa where climatic conditions and vegetation promotes abundant reproduction and distribution of diverse mosquito species, large epidemics of Arboviruses have occurred for instance the Yellow ever epidemic in Nigeria during the mid-1980 which ravaged thousands

\section{Corresponding author: \\ Babatunde Olanrewaju Motayo, Federal Medical Centre, Microbiology Unit, Pathology Department. \\ Email: babatundemotayo@yahoo.com}

African Health Sciences Vol 16 Issue 1, March 2016 of lives ${ }^{2}$. West Nile virus is a highly virulent potentially lethal neurotropic virus widely distributed in the Americas and Europe ${ }^{3,4}$. In Nigeria, WNV infections have been reported $^{5,6}$. The maintenance and spread of WNV is dependent on the relative abundance of the insect vector Culex pipens ${ }^{7}$, Humans are accidental or secondary host of WNV, birds and horses are the primary hosts of this virus and maintain the virus in nature. For outbreaks to occur the primary hosts must be viremic ${ }^{1}$. Vectorial studies have demonstrated the presence of West Nile virus in Culex pipens complex mosquitoes in Nigeria ${ }^{6}$. Apart from WNV, Culex quinquefasciatus is one of the major vectors of Wuchecheria brancrofti infection world-wide, a parasitic infection having various disease manifestations ${ }^{8}$.

A recent study reported Brancroftain filariasis infection among inhabitants of Abule Sowo, a remote village few kilomerters from Abeokuta ${ }^{9}$, Nigeria. Previous studies have also demonstrated the public health implications of high vectorial abundance of Culex pipens complex in Abeokuta ${ }^{10}$. However only Morphometric analysis has 
been done in the identification of Culex pipens complex $^{11,12}$, the molecular identification of this all important insect vector has not been attempted in our environment, despite its use in surveillance and experiment studies elsewhere. There have been reports on the limitation of only morphometric methods in the identification of various Culex species in Nigeria ${ }^{8}$. With reports of existence of hybrid spp of culex pipens complex and misidentification of mosqutoes within the culicine family particularly $C u l e x^{13,7}$. There is need to introduce Molecular biology methods to validate existing morphological classification keys as well as identify hybrid $s p p$ in mapping out the distribution and abundance of Culex spp in Nigeria. The aim of this study was to use Molecular method (PCR) to identify and diferentiate Culex pipens complex and determine the vectorial abundance and seasonal distribution of the vector in some selected residential areas within Abeokuta Metropolis.

\section{Methods \\ Study area}

The current study was conducted at Abeokuta, Ogun State, Nigeria. Abeokuta is the capital city of Ogun State, with co-ordinates, latitude $7010^{\prime} \mathrm{N}$ and longitude 3021 ' $\mathrm{E}$, located in the transitional zone between tropical rain forest and derived savannah in South-Western Nigeria. The city is a rapidly developing city with increasing population density and increased construction of civil infrastructures within the city. Abeokuta is inhabited by the Yoruba speaking tribe in South-Western, Nigeria. There are 2 major seasons, the dry season (November to March) and the rainy season (April to October). The study locations were in 3 urban residential areas located within 2 Major local government areas in Abeokuta, Federal Medical Centre Idi-aba, Kemta estate Located in Abeokuta South Local government area, and Aro community, located in Abeokuta North local government area.

\section{Mosquito capture and identification}

Adult mosquitoes were captured using baiting method in sterile sample bottles by trained volunteers, in 4 randomly selected spots around each selected study location. Volunteers for sample collection presented evidence of vaccination against yellow fever, and were put on Malaria prophylactic treatment throughout the duration of mosquito field collection. Mosquito capture was done between the hours of $3 \mathrm{pm}$ and $8 \mathrm{pm}$. Upon capture Culex mosqui- toes were sorted out by species from other insects using morphorlogical keys as described by Gillet ${ }^{14}$. Male Culex mosquitoes were morphologically identified by their male genitalia under the microscope ${ }^{15}$. Female Culex pipens and Culex quinquefasciatus mosquitoes were morphologically differentiated by using wing measurements' of intersection of costa, subcosta and bifurcation of R2+3 veins, as described by Antunes de Morias et $\mathrm{al}^{16}$, Dehghann et $\mathrm{al}^{17}$

\section{DNA extraction}

Individual Culex mosquitoes previously identified into individual species by morphometric methods were selected according to location of capture, and ground in a sterile porcelain mortar and pestle in serum free, minimum essential medium (MEM). Genomic DNA was extracted from the homogenate using DNA extraction kit from Jena Bioscience ${ }^{\circledR}$ Gmb Germany.

\section{PCR}

Molecular identification of Culexpipens, and Culex quinquefascius was done by multiplex polymerase chain reaction (PCR), amplifying the Acetylcholinestarase gene locus (Ace2 gene) of the mosquito, using a set of previously published primers ${ }^{18}$, in an Applied biosystems (ABI 9700) genetic analyzer Foster city CA. The primer set are ACE quin, 5'-CCT'TCT'TGAATGGCTGTGGCA-3', ACEpip 5'-GGAAACAACGACGTATGTACT-3', B1246s 5'-TGGAGCCTCCTCT'TCACGGC-3'. The cycling condition was one cycle for 950C for 5 mins, followed by 35 cycles of 950C for 30 secs, 550C for 30 secs $720 \mathrm{C}$ for $1 \mathrm{~min}$, and a final extension step of $720 \mathrm{C}$ for 5 mins. The expected band size is 610-bp for culexpipens and 274-bp for culex quinquefasciatus, and both bands showing in hybrid mosquito species.

\section{Data analysis}

Results from field and laboratory studies were recorded, grouped and analyzed using statistical software SPSS 12.0.

\section{Results}

A total of 751 mosquitoes belonging to the genera culex were captured. Distribution of mosquito species showed that Culex quinquefasciatus was the most abundant with 56.6\% $(\mathrm{n}=425)$ and Culex pipens with $43.4 \%$ with $\mathrm{P}>0.05$. Majority of the mosquitoes were female. The seasonal abundance of mosquito vector species peaked between the months of June and July, with Culex quinquefasciatus having a higher distribution of vectors (Figure 1). 


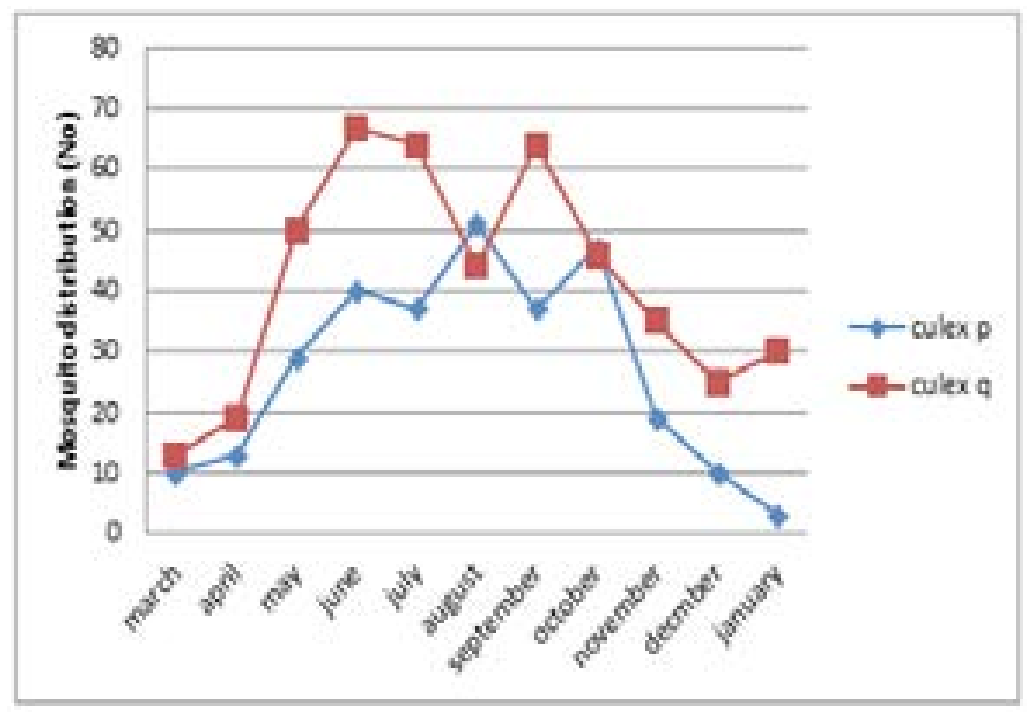

Fig 1: Seasonal abundance and monthly distribution of culex pipens and Culex quinquefasciatus mosquitoes in some residential areas in Abeokuta, Nigeria.

However there was a decline in vector abundance in the month of August which rose again in September. There was a gradual decline in the abundance of both species through the dry months of November to January. Figure 2 shows the gel picture of PCR product of Ace 2 gene of Culex quinquefasciatus.

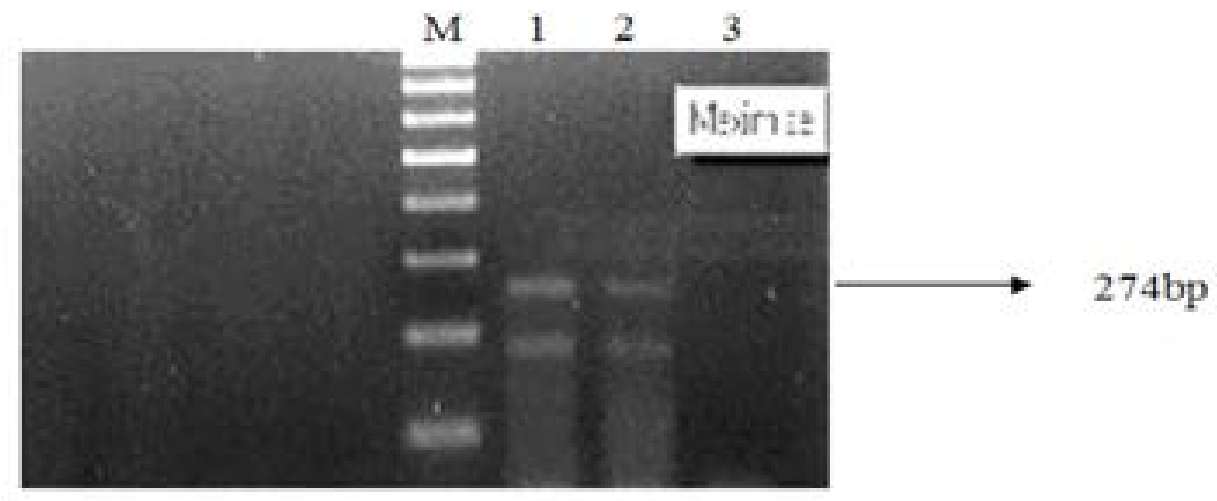

Figure 2: gel picture showing PCR amplication of Ace 2 gene positive Culex quinquefasciatus Lane $1 \& 2$, negative control Lane 3, M DNA ladder (100bp).

Species distribution of Culex pipens complex vectors in the 3 locations namely, Idi-aba, Kemta, and Aro as shown in figure 3. Idi aba recorded the highest distribution of both vectors $42.9 \%(\mathrm{n}=322)$ Culex pipens (139), Culex quinquefasciatus (183). This is followed by vectors caught around Aro community 32\% $(\mathrm{n}=240)$ with Culex quinquefasciatus having a higher level of abundance. Lastly Kemta with a distribution of $25.1 \%(\mathrm{n}=189)$. In all the locations Culex quinquefaciatus had higher level of abundance as in figure 3. 


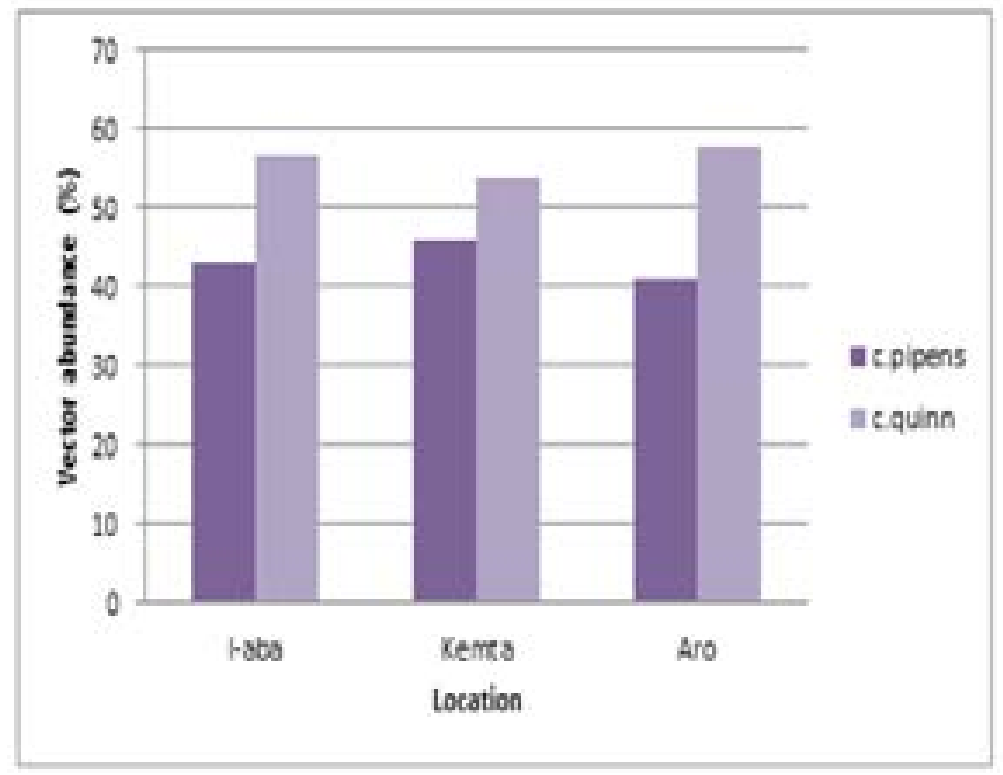

Figure 3: Bar graphs showing distribution of culex pipens complex in 3 different areas in Abeokuta, Nigeria.

\section{Discussion}

The current study surveyed the abundance and species distribution of potential West Nile virus vectors, Culex pipens and Culex quinquefasciatus in 3 residential locations within Abeokuta Metropolis. West Nile virus has not been reported in Abeokuta, this is probably due to unavailability of diagnostic facilities capable to detect the infection in Abeokuta, coupled with poor surveillance activity. Previous reports have however indicated the presence of this virus in nearby Ibadan city ${ }^{6}$. This is an indication that WNV is most likely circulating within the whole of the South-West region of Nigeria. Similarly unconfirmed cases of probable West Nile infection have been reported in children at the Federal medical centre Abeokuta (Nwadike, personal communication).

In a recent study of indoor sampled mosquitoes, the WNV vector culex quinquefasciatus was the $2^{\text {nd }}$ most abundant mosquito sampled in Abeokuta with $32.2 \%$ distribution $^{10}$. Our study not only identified Culex pipens complex but also differentiated the 2 main species using both morphometric characters and molecular methods. Culex pipens and Culex quinquefasciatus mosquitoes are almost morphologically indistinguishable, particularly the females making it very difficult for researchers to identify. This was why we adopted the molecular technique, which has been widely used and documented to be highly specific for the identification of these species of mosquitoes and their hybrids ${ }^{13}$. This method employed PCR amplify- ing a fragment of the Acetycholinestase gene locus of the mosquito (Ace2) and sizing the amplicons in agarose gel. This method has also been used to demonstrate the presence of hybrid species between Culexpipens and Culex quinquefasciatus which has served as valuable information in the surveillance and elimination of this vector in the Americas ${ }^{13,16}$. Seasonal abundance of WNV vectors indicated that both mosquito species were more abundant in the months of May to October, coinciding with the rainy season where rainfall and humidity is high. There was however a decline in the relative abundance of both vectors particularly Culex quinquefasciatus in the months of July and August. A similar trend in seasonal abundance has been reported from Abeokuta ${ }^{10}$, where higher level of vectorial abundance was observed in the rainy months of May to October than the dry months, although in the report of Adeleke et $\mathrm{al}^{10}$ there was a sharp decline in the months of April to July which heralds the peak of the rainy season among Mansonia Africana mosquitoes, the principal vector of plasmodium spp.

A similar trend was observed for Culex quinquefascitus mosquitoes in our current study with a decline in the midrainy season between the months of June and August. It has been suggested that this observation might be due to the heavy rainfall occurring in the peak of the rainy season, thus washing away breeding sites, strand larvae and damage mosquito eggs thereby causing a reduction in the abundance of adult mosquitoes ${ }^{19}$. Species distribu- 
tion according to location of capture showed that Culex quinquefasciatus was the most abundant species in all three locations sampled. This is in accordance with previous reports which have reported a high level of abundance of Culex quinquefasciatus in relation to other Culex species ${ }^{10}$. No hybrid species were encountered in the current study, although this may not represent the true picture as a major limitation to this study was our inability to consistently test each sampled mosquito using PCR as a result of cost. Only a small proportion of identified mosquito species were tested using PCR. Idi-aba community recorded the highest proportion of mosquitos captured followed by Aro community then Kemta. This observation might be due to the fact that the locations of capture at Kemta were in largely developed residential areas, devoid of potential breeding sites for mosquitoes, unlike areas sampled at Idi-aba where there are various uncompleted buildings and items such as old tyres and cans that can retain water and promote breeding of mosquitoes. The high population of these mosquitoes in areas inhabited by humans gives concern, because of the risk of infection with WNV should an outbreak occur or the possibility of repeated outbreaks where there is presence of vireamic birds or other primary hosts. In the USA, where there is established surveillance for WNV disease, presence of hybrid species between Culex pipens complex, has been associated with rapid spread of $\mathrm{WNV}^{20}$.

\section{Conclusion}

The current report highlights an overwhelming evidence of the presence of WNV vectors in Abeokuta, Southwest, Nigeria. This reveals that inhabitants of Abeokuta city are at great risk of WNV infection, we advocate for intensified surveillance for $\mathrm{WNV}$, distribution of insecticide treated bed nets, as well as other vector control measures such as clearing of gutters, drains and disposal of unused containers and bad tyres in order to reduce potential breeding sites of mosquitoes within residential areas in Abeokuta and Nigeria.

\section{Aknowledgements}

The authors will like to acknowledge the contribution of Dr MA Adeleke for supporting this research with useful materials. The effort of Mr Opayele is also appreciated during the process of mosquito identification. The authors declare that there are no conflicts of interest.

\section{References}

1. Monath TP, Arroyo J, Miller C, Guirakhoo E. (2001). West Nine virus vaccine. Virol. 1: 1-11.

2. Nasidi A, Monath TP, DeCock K, Tomori O,Cordelleir R, Olaleye OD, Harry TO, Adeniji A, Sorungbe AO, Ajose-Cocker AO, van-Der Laan G, Oyediran ABO (1989). Urban yellow fever in Nigeria 1987. Trans Roy Soc Trop Med Hyg. 83: 401-406.

3. Amraoui F, Kirda G, Bouattour A, Rhimm A, Daaboub A. (2012). Culex pipens, an experimental efficient vector of West nile virus and Rift valley fever viruses in the Maghreb region. PLoS ONE. 7(5); e36757. doi:10.1371/ jornal.pone.0036757.

4. Andreadis TG, Anderson JF, Vossbrink CR, Main AJ. (2004). Epidemiology of West Nile virus in Conneticut; a five year analysis of mosquito data 1999-2003. Vector Brorne Zoonotic Dis. 4; 360-378.

5. Omilabu SA, Olaleye OD, Aina Y, Fagbami H. (1990). West Nile complement fixing antibodies in Nigerian domestic animals and humans. J Hyg Epidemiol Microbiol Immunol. 34(4): 357-363.

6. Baba MM, Sanon M, Diop O, Adeniji JA, Olaleye OD. (2006). West Nile virus in mosquitoes and febrile patients in a semi-arid zone in Nigeria. J Am Sci. 2(2): 28-34.

7. Rudolf M, Czajka C, Borstler J, Melaun C, Jost H, von Thien H, Badusche M, Becker M, Schmidt-Chanasit J, Kruger A, Tannich E, Becker S. (2013). First nationwide surveillance of Culex pipens complex and Culex torrentium mosquitoes demonstrated the presence of $\mathrm{Cu}-$ lex pipens complex biotype pipens/molestus Hybrids in Germany. PLOS ONE. 8(9). e71832.

8. Adeleke MA, Mafiana CF, Idowu AB, Adekunle MF and SO Sam-Wobo. (2008a). Mosquito laval habitats and public health implications in Abeokuta, Ogun State, Nigeria. Tanzanian Journal of Health Research, 10(2); 103-107. 9. Ojurongbe O, Akinbo JA, Ojiogwa IJ, Bolaji OS, OA Adeyeba. (2010). Lyphatic filariasis in a rural community in Nigeria: The challenge ahead. Afr J Med Med Sci. 39: 179-183.

10. Adeleke MA, Mafiana CF, Idowu AB, SO Sam-Wobo, OA Idowu. (2010). Population dynamics of indoor sampled mosquitoes and their implications in disease transmission in Abeokuta, south-western, Nigeria. J Vector Borne Dis. 47; 33-38.

11. Mafiana CF, Anaeme L, Olatunde GL. (1998).Breeding sites of larval mosquitoes in Abeokuta, Nigeria. Tanran J Entomol. 15: 136-144. 
12. Adeleke MA, Mafiana CF, Idowu AB, Adekunle MF and BM Dansu. (2008b). Morphometric studies on culex quinquefaciatus and Mansonia Africana (Diptera; culicidea) in Abeokuta, south-western, Nigeria. Tanzanian Journal of Health Research, 10(2); 99-102.

13. Diaz-Badillo A, Bollin BG, Perez-RamirezG, Moore GC, Martinez-Munoz JP, Padilla-Viveros AA, CamachoNuez M, Beaty BJ and M Munoz. (2011). The distribution of potential West nile virus vectors culex pipens and culex quinqueasciatus (Diptera: Culicidea) in Mexico city. Parasites \& Vectors 4:70. doi :10.1186/1756-3305. 4.70. 14. Gillett JD. (1972). Common African mosquitoes and their Medical importance. William Heinemann Medical books Ltd. London: 236.

15. Sundararamann S. (1949). Biometrical studies on intergradation on the genitalia of certain populations of culex pipens and culex quinquefasciatus in the United States. Am J Hyg. 50: 307-314.

16. Antunes-de Morais S, Moratore C, Suesdek L, Marrel- li MT. (2010). Genetic-morphometric variations in culex quinquefaciatus from Brazil and La Plata, Argentina. Mem Inst Oswaldo Cruz. 105(5) http://dx.doi.org/10.1590/ S0074-02762010000500012.

17. Dengham H, Moosa-Kazemi SH, Sadraei J, Soleimani H. (2014). The ecological aspects of Culex pipens (Diptera: Culicidae) in central Iran. J Arthropod Borne Dis. 8(1): 35-42.

18. SmithJL, Fonseca DM. (2004). Rapid assays for the identification of Culex pipens complex, their Hybrids and other sibling species (Diptera: culicidae). Am J Trop Med Hyg. 70: 339-345.

19. Amusan AAS, Mafiana CF, Idowu AB, Olatunde GO. (2005). Sampling mosquitoes with CDC light-traps in rice field and plantation communities in Ogun state, Nigeria. Tanzania Health Res Bull; 7: 111-6.

20. Fonseca DM, Keyghobadi N, MalcolmCA, Mehmet C, Schaffner F, Mogi M, Flesicher RC, Wilkerson RC (2004). Emerging vectors in the culex pipens complex. Science. 303; 1535-1538. 